\title{
Analysis of Maize Value Addition among Entrepreneurs in Taraba State, Nigeria
}

\author{
Ater, P. I.; Aye, G.C. and Daniel A*
}

Department of Agricultural Economics, Federal University of Agriculture, Makurdi, Benue State, Nigeria.

*Afiniki Daniel-Corresponding Author (afinikidanie195@gmail.com)

\begin{abstract}
This study analyzed maize value addition among maize entrepreneurs in Taraba State, Nigeria. A multi-stage sampling procedure was used to collect primary data from two hundred and twelve respondents (212), using structured questionnaire. Data were analyzed using descriptive statistics, Value addition model, ANOVA, multinomial logistic regression, log likelihood test ratio and factor analysis. The result of the study revealed that most (62.3\%) respondents were males. $61.3 \%$ were within the productive age of 21-40 years. Majority (71.1\%) were married with household sizes of 6-10. The total of (32.8\%) respondents of them had secondary school education, (46.6\%) had processing experience of between 6-10 years in processing as their major occupation. proportionate (49.2\%) of total respondents had non-farm income of $\$ 150,001$ per annum. Results of the value addition analysis showed that maize processed as boiled maize is more profitable with a mean of $\$ 130$, 900 per annum. The result from the multinomial logistic regression on choice of maize processing enterprises revealed that sex had negative coefficient, which implied that male respondents preferred grain production enterprise rather than processing into akamu, corn flour, massa and boiled maize. Also age had negative coefficient, implying that age increase tends to favour grain production than processing. In relation to processing constraints, the maize processing value chain was hampered by the following: inadequate processing facilities, inadequate credit/funds, high cost of transport and inadequate access to inputs. The study concluded that maize value addition is a profitable enterprise and entrepreneurs should be encouraged to venture into it. Also the Agricultural Development Project Programme should send extension agents to processors to encourage processing diversification especially into poultry feeds.
\end{abstract}

Keyword- Value addition, entrepreneurs, maize, processing, enterprise.

\section{INTRODUCTION}

\subsection{Background to the Study}

Maize is a very important food crop for human beings and livestock. It provides energy, vitamins and negligible amount of protein. Output of maize has generally continued to increase in Nigeria. For instance maize production increased from 10,813,980 tonnes in 2016 to $12,107,580$ tonnes in 2017 representing 11.96 percent increase National Agricultural Extension and Research Liaison Services (NAERLS, 2017). Africa produces just 6.5 percent of the worlds maize with Nigeria being the largest African producer. Output of maize in Nigeria has continued to increase, however its contribution to Gross Domestic Product is still low as observed by (FAO, 2008). This is so, because a negligible part of the produce is formally exported while a good proportion is consumed locally with negligible value addition (Food and Agriculture Organization (FAO, 2012).

Maize is an important grain cereal in Nigeria, is wildly cultivated by almost all farmers because of its high economic value and high adaptability in the ecological zones of the rainforest and the derived Savannah zones of Nigeria. In addition, maize has been in the diet of Nigerians for centuries. It started as a subsistence crop and has gradually become a more important crop, and has now risen to be a major commercial crop on which many agro-based industries depend for raw materials (Iken and Amusa, 2016).

About 28 food items or dishes and 6 medical values of maize were identified by (Abdulrahaman and Kolawole., 2008). Some of these include hot and cold pap, 'tuwo', 'massa', 'couscous', 'gwate', 'nakia', 'dambu','dakuwa', 'Popcorn', cooked and roasted maize. These authors Abdulrahaman and Kolawole (2008) opined that analysis of maize value chain involves all factors of production including land, labor, capital, technology, and inputs as well as all economic activities including input supply, production, transformation, handling, transport, marketing, and distribution necessary to create, sell, and deliver a 
product to a certain destination. Value chain studies are important because the results yield interested stakeholders and company's ability to understand and optimize the activities that lead to its competitiveness and high profit levels (Keyser, 2006). Maize is a multipurpose crop because every part of its plant has economic value. The stems and leaves are used for feeding cattle and the seeds are used for food, livestock feeding and pharmaceuticals.

\subsection{Problem Statement}

Over the years in Taraba State precisely entrepreneurs of maize production enterprise and other stakeholders in maize industry have continued to be poor with low income, as observed in the works of Gani and Adeoti (2011). These authors identified the cause of these low level of income and poverty on government negligence of the industry as well as the extreme poverty of the stakeholders who could not participate in effective marketing to turn around economic fortune to their favour. Thus leading to consumption of almost all of the produce year round with little or no processing activities. Where related relevant local research could have provided an insight into the situation, there scarcely exist any.

Although a lot of research has been conducted on maize production and marketing in some States of the Federation, however little work has been done on maize value addition in Nigeria. For instance, adoption of cassava value added innovation and its implication in rural livelihood in Abia State (Chidozie, 2014). Capacity building on Cocoyam value addition training for rural women in Abia State (Onuekwusi et al., (2016). Yam value chain, constraints and opportunities for small scale farmers in the middle belt Nigeria (Damulak, 2012). This and many related studies have been conducted in Nigeria; however, there is a gap of information on analysis of maize value addition among maize entrepreneurs in Taraba State. The need for the conduct of this research becomes an obvious necessity in filling the existing gap.

\subsection{Aim and Objectives of the Study}

The main objective of this study is to analyze maize value addition among maize entrepreneurs in Taraba State, Nigeria.

1.4 The specific objectives of the study are to:

i. describe the socioeconomic characteristics of the respondents.

ii. identify the different forms of processed maize.

iii. determine the profitability of value added on maize.

iv. analyze the factors influencing choice of maize value added enterprise v. identify the constraints associated with maize value addition.

The following hypotheses were tested:

i. The maize processing value chain in Taraba State is not profitable.

ii. Socio-economic characteristics of maize processors do not have significant effect on their choice of maize value added enterprise.

\section{METHODOLOGY}

\subsection{Study Area}

This study was conducted in Taraba State, Nigeria. Taraba State is situated in the North Eastern part of Nigeria and it lies between latitude $6^{0} 25^{\prime} \mathrm{N}$ and $9^{0} 30^{\prime} \mathrm{N}$ and longitude $9^{0} 30^{\prime} \mathrm{E}$ and $11^{0} 45^{\prime} \mathrm{E}$. The State has a land mass of $54,428 \mathrm{~km}^{2}$ and population estimate of 2,294,800 million (National Bureau of Statistics., 2016). It is bounded by Bauchi and Gombe States in the North- East and Adamawa on the East, and Plateau State in the North-West. The State is further bounded to the west by both Nasarawa and Benue States, while it shares an international boundary with the Republic of Cameroun to the South and South-East (Oruonye and Ahmed, 2017). Taraba State consists of Sixteen (16) Local Government Areas.

\subsection{Sampling and Sample Size Selection}

The state comprises three agricultural zones, the Northern, Central and Southern zones. A multi-stage sampling procedure was adopted. Producers, marketers, processors and transporters enterprises were the target for this study. Firstly, purposive sampling was adopted, to select two agricultural zones, the Central and Northern zones, noted for high level of maize production. The second stage involved purposive selection of five Local Governments Areas from the two zones, involved in high level of maize production. These were Gashaka, Gassol and Bali from the Central zone, Jalingo and Ardo-kola from the Northern zone. Thirdly communities from each Local Government Area were selected by simple random sampling technique. Fourthly, a sampling frame was developed for each of the rural communities using proportional allocation of $5 \%$ (0.05) across board, a total of 212 respondents were selected as a sample size.

Primary data were collected for the study. Data were obtained through administration of a well structured questionnaire and administered by the researcher and trained enumerators to maize producers, transporters, processors and marketers. Descriptive statistics which involves the use of frequencies, percentages and means were used to analyze objectives $\mathrm{i}$ and ii, Value addition model was used to analyze objective iii, Multinomial 
logistic regression was used to analyze objective iv, Factor analysis was used to achieve objective v, ANOVA was used to test hypotheses one (i), Log Likelihood test ratio was used to test hypotheses two (ii).

2.2 Model Specification: The following models were adopted for data analysis

\section{Multinomial Logistic Regression model}

The Multinomial logistic regression model is generally specified in equation 1

$$
P i(A i=j)=\frac{\exp (X i \beta j)}{\sum_{k}^{i}=0 \exp (X i \beta i)}
$$

where:

$(\mathrm{i}=0,1 \ldots \mathrm{j})$

$\mathrm{A}_{\mathrm{i}}=$ random variable representing choice of a particular maize stakeholder enterprise

$\mathrm{X}_{1}-\mathrm{X}_{10}=$ explanatory variable

$\mathrm{X}_{1 \ldots \ldots . . . . . . . .}$ Age

$\mathrm{X}_{2 \ldots \ldots \ldots \ldots . . . . . . . S e x}$

$\mathrm{X}_{3} \ldots \ldots \ldots \ldots . . . . . . .$. Marital status

$\mathrm{X}_{4} \ldots \ldots \ldots . . . . .$. Level of education

$\mathrm{X}_{5} \ldots \ldots \ldots . . . .$. Household size

$\mathrm{X}_{6 \ldots \ldots \ldots . . . . . A c c e s s}$ to credit

$\mathrm{X}_{7 \ldots \ldots \ldots . . .}$ Membership of cooperative society

$\mathrm{X}_{8} \ldots \ldots . .$. Non farm income

$\mathrm{X}_{9} \ldots \ldots \ldots . . .$. Experience in processing

$\mathrm{X}_{10 \ldots \ldots . . .}$ Value addition

$\mathrm{A}_{1}=$ random variable representing choice of a particular marketing channel, and

$\mathrm{X}_{1}=$ explanatory variables such as socio economic, institutional and marketing factors.

\subsection{Value Addition model}

Value Addition model was used to examine the most profitable maize processing value chain, which is simply the difference between the total revenue receipts and the total variable cost as expressed in equation 2,

i.e VA=TRR-TVC ... 2

Where, $\mathrm{VA}=$ Value Added

TRR=Total Revenue Receipts and

$\mathrm{TVC}=$ Total Variable Cost

\subsection{Analysis of variance (ANOVA)}

The analysis of variance technique enables the determination of the number of relevant factors (or causes) of variation and the logical significance of each one of them. This is specified in equation 3 .
$F_{\text {ratio }}=\frac{V_{b}}{V_{w}}$

2.5 Factor Analysis

Factor analysis is a method for investigating whether a number of variables of interest $\mathrm{Y}_{1}, \mathrm{Y}_{2} \ldots \ldots ., \mathrm{Y}_{1}$, are linearly related to a smaller number of unobservable factors $F_{1}, F_{2}, \ldots \ldots \ldots, F_{k}$.

The factor analysis model expresses the variation and covariation in a set of observed continuous variables $y(j=1$ to $p$ )

As a function of factors $\eta(k=1$ to $m)$ and residuals $\varepsilon(j=1$ to $p$ ).

For person $i$,

$y_{i 1}=v_{1}+\lambda_{11} \eta i_{1}+\lambda_{12} \eta i_{2}+\ldots+\lambda_{1} k \eta_{I} k+\ldots+\lambda_{1} m \eta i m+\varepsilon i_{1}$

$y i j=v j+\lambda j_{1} \eta i_{1}+\lambda j 2 \eta i_{2}+\ldots+\lambda j k \eta i k+\ldots+\lambda j m \eta i m+\varepsilon i j$ ....4

$y i p=v p+\lambda p_{1} \eta i_{1}+\lambda p_{2} \eta i_{2}+\ldots+\lambda p k \eta i k+\ldots+\lambda p m \eta i m+$ sip

where,

$v j$ are intercepts

$\lambda j k$ are factor loadings

$\eta i k$ are factor values

eij are residuals with zero means and correlations of zero with the factors

\section{RESULTS AND DISCUSSIONS}

\subsection{Socio-Economic Characteristics of the Respondents}

Table 1 shows that majority $(61.3 \%)$ of the respondents fell within the age bracket of 21-40 years while (36.8\%) of the respondents fell within the age bracket of $41-60$ years. The mean age was 37.78 years. This indicates that most of the respondents were young, active and of productive age. Table 1 also indicated that $62.3 \%$ of the respondents were males, while $37.7 \%$ of the respondents were females. This implies that majority of the respondents were males. This agrees with the findings of Ogunniyi and Omotesho (2011) and Osondu et al., (2014) who reported that most of the respondents were males. Majority (71.1\%) of the respondents were married, $20.6 \%$ of the respondents were single, $6.4 \%$ of the respondents were widowed and $2.0 \%$ of the respondents were divorced. This implies that the area under study was dominated by married people. It was also found that $32.8 \%$ of the respondents had secondary school education, $20.6 \%$ of the respondents had primary school education. This implies that majority of respondents were 
literate. This agrees with the findings of Ogunniyi and Omotesho (2011) that literacy of respondents was high, table 1 further indicated that $40.7 \%$ of the respondents had a household size of $6-10,(31.4 \%)$ had a household size 1115. This implies that respondents had large household size which could serve as a source of labour for maize value added activities. The mean of the household size was 9.98. This agrees with the findings of Abdeleteif and Siegfried (2015) who stated that large household size may translate to higher usage of family labour. The result also shows that $49.2 \%$ of the respondents had non-farm income of $\$ 150001,16.2 \%$ of the respondents had a non-farm income of $\$ 500$, 000, likewise $16.2 \%$ of respondents had a nonfarm income of between $\$ 5000$ - $\$ 10000$. This shows that maize processors are low income earners and that is why most respondents operate on a low scale of maize processing. The mean of non-farm income of the respondents stood at $\$ 187553$. This agrees to the findings of Bakari (2016) that respondents are low income earners, hence they may not possess the financial muscle required to expand the enterprise. About (47\%) of the respondents had processing experience of between 6 and 10 years, $24 \%$ of the respondents had experience of between 11-15 years, $19.1 \%$ of the respondent had experience of $<5$ years. This shows that the respondents are experienced and can improve with more financial support. This agrees with findings of Dauda and Ndanitsa (2009) that the length of experience of a working population in any occupation determines its performance and enables managers to overcome problems previously encountered in the production process. Majority $(91.7 \%)$ of the respondents had no access to formal credit while just $8.3 \%$ had access to formal credit which indicates the reas on for the low level of processing as lack of access to formal credit, thus stakeholders can improve when supported. This agrees with the findings of Oladejo and Adetunji (2012) that only $3.7 \%$ of respondents have access to formal credit. It also agrees with the findings of Abdeleteif and Siegfried (2009) that only $14 \%$ have access to formal credit. Table 2 also shows that $88.3 \%$ of the respondents did not belong to any cooperative society. It was found that only $11.8 \%$ belong to cooperative societies. This clearly indicates that most of them do not have any useful other source of credit and information that can help them improve their productivity. This agrees with the findings of Bakari (2016) that most respondents do not belong to a cooperative society, so they could miss out on the opportunity to participate in any government programmes which is communicated through cooperative societies.

Table.1: Distribution of Respondents According to Socio-economic Characteristics $(n=204)$

\begin{tabular}{|c|c|c|c|}
\hline Variables & Frequency & Percentage (\%) & Mean \\
\hline \multicolumn{4}{|l|}{ Sex } \\
\hline Male & 127 & 62.3 & 102.0 \\
\hline Female & 77 & 37.7 & \\
\hline Total & 204 & 100.0 & \\
\hline \multicolumn{4}{|l|}{ Age(Years) } \\
\hline$\leq 20$ & 4 & 2.0 & \\
\hline $21-40$ & 125 & 61.3 & \\
\hline $41-60$ & 75 & 36.8 & 68.0 \\
\hline Total & 204 & 100.0 & \\
\hline \multicolumn{4}{|l|}{ Marital Status } \\
\hline Single & 42 & 20.6 & \\
\hline Married & 145 & 71.1 & 51.0 \\
\hline Widowed & 13 & 6.4 & \\
\hline Divorced & 4 & 2.0 & \\
\hline Total & 204 & 100.0 & \\
\hline \multicolumn{4}{|l|}{ Level of Education } \\
\hline Non formal education & 28 & 13.7 & \\
\hline
\end{tabular}


Primary

Secondary

42

Tertiary

Degree

Total

\section{Household size}

$\leq 5$ 32

6-10

64

$11-15$

16 and above

Total

67

30

31

204
20.6

32.8

14.7

15.2

100.0

15.7

40.7

31.4

12.3

100.0
39.6

204
51

20.5

20.5

9.3

49.2

100.0
$150001+$

Total
Experience in processing and Marketing (years)

$\leq 5$

6-10

11-15

16 and above

Total
39

95

19.3

47.0

24.3

9.4

100.0

8.3

91.7

Access to formal credit

Yes

No

Cooperative society

Yes

No

\section{Source of inputs}

Middlemen

Retailers

Wholesalers
116

69

19
11.8

83.3
Table 2 shows that maize processed into akamu has a mean of $\$ 127,714.63$, maize processed into corn flour has an annual mean of $\$ 112,609.677$, maize processed into massa has an annual mean of $\$ 119,283.333$, maize processed into boiled corn annually has a mean of $\$ 130,900.00$, maize processed into roasted maize annually has a mean of $\$ 121,160.00$. This indicates that boiled maize is more profitable compared to the other products annually in the study area. However, these annual means are generally low monetarily. This agrees with the findings of Umeh et al., (2011) that the income of small scale enterprises are low, so government should encourage the growth of small business by giving them the necessary assistance as regards to fund 
raising and equally advice them on how to utilize it

effectively.

Table.2: Value Addition of Maize Annually (Naira)

\begin{tabular}{llllll}
\hline Description & Number & Mini & Max & Mean & Std dev \\
\hline Akamu & 41 & 43000.0 & 1237200 & 12771463 & 183323.35 \\
Corn flour & 31 & 48000.0 & 225000 & 112609.677 & 41948.25 \\
Massa & 30 & 13700.00 & 170000 & 119283.33 & 42119.8788 \\
Boiled & 6 & 72000.00 & 224000 & 130900 & 59316.979 \\
Roasted & 30 & 1000.00 & 365000 & 121160 & 72717.3 \\
\hline
\end{tabular}

Source: Field Survey (2017)

\subsection{Forms in Which Maize is Processed into in the Study Area}

Table 3 indicates that $32.8 \%$ of the respondent process their maize into corn flour, $19.1 \%$ process their maize into massa, $18.1 \%$ process their maize into akamu, $18.7 \%$ process their maize into roasted corn, $11.3 \%$ of the respondent process their maize into grains and $5.9 \%$ process their maize into boiled maize. This shows that most of the maize is processed into corn flour in making tuwo because majority of the households consume tuwo as their major meal in the study area. This study agrees with the finding of Thomas (2010) who reported that maize are mostly used for processing into flour, maize are roasted or boiled and eaten as a snack.

Table.3: Forms Maize is Processed into in the Study Area

\begin{tabular}{lll}
\hline Products & Frequency(f) & Percentage (\%) \\
\hline Akamu & 37 & 18.1 \\
Cornflour & 67 & 32.8 \\
Massa & 39 & 19.1 \\
Boiled & 12 & 5.9 \\
Roasted & 26 & 12.7 \\
Grains & 23 & 11.3 \\
Total & 204 & 100.0 \\
\hline
\end{tabular}

Source: Field Survey (2017)

3.4 Multinomial Logistic Regression of Selected Socio Economic Variables of Respondents.

The result of the multinomial logistic regression is presented in table 4 and the corresponding marginal effects in table 5. The result indicates a likelihood ratio $\left(\chi^{2}\right)$ value of 204 which was significantly different from zero $(\mathrm{P}<0.01)$ at $1 \%$ level. This confirmed that, the slope of the coefficient of the independent variables is significantly different from zero. This implies that the socio-economic characteristics included in the regression equation are significantly related to the choice of maize value addition enterprises by the processors. This result rejected the null hypothesis that socio-economic characteristics of maize processors have no significant influence on the choice of maize value added enterprise. The sign of their coefficient have important influence on the type of enterprise related to the reference category which is grain production enterprise in this respect. Increase in the coefficient with positive signs favored their choice as against the alternative non processing reference category. While increase in the variable with negative coefficient favored the choice of the reference category against the variable in question. In accordance to prior expectation the coefficient of sex was negative and statistically significant with akamu (-4.42), corn flour (2.12), massa (-3.31) and boiled maize (-1.77) at 5\% level. This implies that male participation in processing unfavored maize processing like akamu, corn flour, massa and boiled maize. It means that female processors are involved in processing these products more than their male counterparts. This agrees with the findings of FAO. (2000) that women are basically responsible for processing most food for storage and it also agrees with the programme Strategies for increasing food production and food security in Nigeria that traditionally women have been the custodian of most primary on farm processing operation and post harvest operations. The marginal effects of these products were $-0.276,-0.09,-0.163$ and -0.008 respectively. This implies that a $1 \%$ increase in male participation reduced their choice of processing akamu, corn flour, massa and boiled maize by $0.276 \%, 0.09 \%, 0.163$ and $0.008 \%$ respectively. The coefficient of age was negative and statistically significant with akamu (-0.09) and massa (0.122). This implies that increase in age of processors favored grain production as against processing it into akamu and massa. The marginal effects for these variables were ($0.09)$ and (-0.018). This means that at $1 \%$ increase in age of processors reduced their choice of processing maize into akamu and massa by 0.09 and $0.018 \%$ respectively. The coefficient for level of educational level is positive and statistically significant with akamu (0.48) at 5\% level. This implies that the level of education favored processing into akamu as against grain production. The marginal effect for the variable was 0.071 . This means that a $1 \%$ increase in 
level of education increase their choice of processing maize into akamu by $0.07 \%$. The coefficient of household size is positive and statistically significant with akamu (0.15) and (0.192) corn flour against grain production. The marginal effects for these variables were (0.023) and (0.427) respectively. This means $1 \%$ increase in household size increase their choice of processing maize into akamu and corn flour by $0.023 \%$ and $0.42 \%$ respectively. This is because increased household size provides cheap family labour for the intensive tasks needed for akamu and corn flour processing at small scale level. The coefficient of net farm income is negative and statistically significant with akamu (-6.39) and corn flour (-8.45). This implies that increase in Net farm income favored grain production as against processing maize into akamu and corn flour. Following that sequence, the marginal effects for these variables were (-9.34) and (-5.07). This implied that increase in Net farm income of processors reduced their choice of processing akamu and corn flour, by $9.34 \%$ and $5.07 \%$ respectively. This conforms to the findings of Jay. (2018) that if an enterprise is continually unprofitable, then get rid of it and carefully consider options.

Table.4: Multinomial Logistic Regression Showing Socio-Economic Factors Influencing Choice of Maize Processing Enterprise

\begin{tabular}{llllll}
\hline Variables & Akamu & Cornflour & Massa & Boiled & 4 \\
& 1 & 2 & 3 & 4 & 5 \\
\hline Sex & $-4.42^{*}$ & $-2.12^{*}$ & $-3.31^{*}$ & $-1.77^{*}$ & -17.72 \\
Age & $(-5.63)$ & $(-3.08)$ & $(-5.04)$ & $(-2.36)$ & $(0.03)$ \\
& $-.090^{* *}$ & 0.03 & $-0.122^{*}$ & 0.018 & -0.018 \\
Education & $(-2.18)$ & $(0.78)$ & $(-2.84)$ & $(0.37)$ & $(-0.43)$ \\
& $0.48^{* *}$ & -0.462 & 0.299 & -0.102 & 0.393 \\
Household size & $(2.05)$ & $(-1.63)$ & $(1.28)$ & $(-0.37)$ & $(1.50)$ \\
& $0.15^{* *}$ & $0.192^{* *}$ & -0.95 & 0.090 & -0.068 \\
Access to credit & $(1.99)$ & $(2.36)$ & $(-1.16)$ & $(1.00)$ & $(0.74)$ \\
Membership & -1.92 & -1.67 & -1.134 & -0.234 & -1.47 \\
cooperative & & $(-1.10)$ & $(-1.11)$ & $(-0.20)$ & $(-1.35)$ \\
NFI & 0.14 & 0.841 & -0.146 & 0.723 & 0.255 \\
& $(0.14)$ & $(0.73)$ & $(-0.17)$ & $(0.73)$ & $(0.28)$ \\
Exp pro & $-6.39 *$ & $-8.45^{* *}$ & $2.21 \mathrm{e}-0.6$ & $-2.05 \mathrm{e}-06$ & $-2.45 \mathrm{e}-06$ \\
& $(-2.53)$ & $(-2.30)$ & $(1.13)$ & $(-0.73)$ & $(-0.98)$ \\
Constant & $-0.114)$ & -0.130 & -0.014 & -0.147 & -0.132 \\
& $(-1.51)$ & $(-1.53)$ & $(-0.16)$ & $(-1.57)$ & $(-1.58$ \\
\hline
\end{tabular}

Source: Field Survey (2017)

$* \mathrm{dy} / \mathrm{dx}$ is for discrete change of diary variable from 0 to 1

Reference category is 6 which is grain production Number of observation 204

LR Chi-chi square 206.99

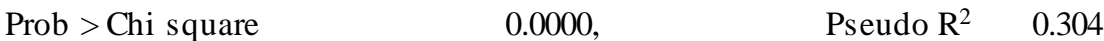

$* *, *$ significant at $1 \%$ and $5 \%$ levels respectively (..) Represents various $\mathrm{t}$-ratio

Table.5: Marginal Effects for Socio Economic Factors Influencing Choice of Maize Processing Enterprise

\begin{tabular}{llllll}
\hline Variable & 1 & 2 & 3 & 4 & 5 \\
& $(\mathrm{dy} / \mathrm{dx})$ & $(\mathrm{dy} / \mathrm{dx})$ & $(\mathrm{dy} / \mathrm{dx})$ & $(\mathrm{dy} / \mathrm{dx})$ & $(\mathrm{dy} / \mathrm{dx})$ \\
\hline Sex & -0.276 & -0.009 & -0.163 & 0.008 & -0.254 \\
Age & -0.009 & 0.005 & -0.018 & 0.006 & 0.000 \\
Education & 0.071 & -0.427 & 0.039 & -0.022 & 0.000 \\
Household & 0.023 & 0.0118 & -0.027 & 0.006 & -0.000 \\
Access to credit & -0.161 & -0.054 & -0.098 & 0.35 & -0.000 \\
Membership of & 0.008 & 0.053 & -0.059 & 0.060 & 0.000 \\
\hline
\end{tabular}


cooperative

NFI

$-9.34 \mathrm{e}-07$

$-5.07 e-07$

$8.18 \mathrm{e}-07$

$-4.38 \mathrm{e}-08$

$-9.71 \mathrm{e}-10$

Exp

$-0.126$

$-0.006$

0.007

$-0.009$

$-0.000$

Constant

\section{Source: Field Survey (2017)}

\subsection{Constraints to Maize Value Addition}

Table 6 presents factor analysis of constraints to maize value addition in the study area. The analysis reveals two major constraints namely: 1, socio-economic infrastructural constraints) and 2 (Marketing constraints). These were derived from loadings of 0.400 and above, while those with loadings less than 0.400 were ignored. This agrees with the findings of Abiyong (2017), who derived variable loadings of 0.400 and above, while those with loading less than 0.400 were not considered. The variables that (loaded high under factor 1) socio-economic infrastructural constraints were dominated by inadequate provision of processing equipment (0.419), inadequate availability of funds (0.669), high cost of products $(0.661)$, poor transportation system (0.409), high cost of transportation (0.455). This was revealed by Olayemi (1982) that government places emphasis on increased food production without commensurate attention to food distribution in regards to funding. The variables that loaded high under factor 2 (marketing constraints) were high cost of inputs (-578), high cost of onloading/offloading (0.640) and access to input (0.714). The result agrees with Ajala and Adesehinwa (2007) who also reported high cost of transportation as constraints that may lead to market inefficiency.

Table.6: Factor Analysis of Constraints Associated with Maize Value Addition

\begin{tabular}{|c|c|c|}
\hline Variables & Factor 1 & Factor 2 \\
\hline Inadequate provision of processing facilities & $0.419^{*}$ & 0.204 \\
\hline Inadequate availability of funds & $0.669 *$ & -0.187 \\
\hline High cost of products & $0.661 *$ & -0.336 \\
\hline Cost of inputs & 0.358 & $-0.578 * *$ \\
\hline Poor transport system & $0.409 *$ & 0.077 \\
\hline High cost of trans port & $0.455^{*}$ & 0.062 \\
\hline High cost of & $0.414 \mathrm{E} 0 \quad 2$ & $0.640 *$ \\
\hline \multicolumn{3}{|l|}{ loading/offloadig } \\
\hline Access to inputs & 0.020 & $0.714^{*}$ \\
\hline
\end{tabular}

Source: Field Survey (2017)

Method : Varimax

*Factor 1: Socio-economic infrastructural constraints

*Factor 2: Marketing constraints

\section{CONCLUSION AND RECOMMENDATIONS}

The study examined analysis of maize value addition among entrepreneurs in Taraba State and concluded that maize value addition is a profitable enterprise which entrepreneurs are encouraged to venture into and it is revealed that value addition is essential to maize entrepreneurs in the study area. On the basis of results of the study, it was concluded that maize value addition among entrepreneurs in the study area was hampered by constraints. This can be improved when infrastructure are put in place.

Based on the results of the study and conclusion drawn, the following recommendations were made:
1. The result revealed that processors have low level of educational qualification. Education is very important in achieving any development; to achieve this there should be effective educational training to strengthen the processing enterprise.

2. Extension agents to be sent to processors to encourage processing into more products, like processing into animal feed. It is important that processing should follow modern trends revealed from research.

3. Maize processors should be guided by Extension agents to register themselves into cooperative societies in order to harness the benefit of such 
group, one of which is the ease of getting access to credit facilities from both formal and informal financial institutions.

4. Government should provide infrastructure such as roads, transport and Storage facilities for processors to have ease of transportation, low cost of products and also getting access to the products

\section{RERERENCES}

[1] Abdeleteif, H.I. and Seigfried, B. (2013). Access to Micro Credit and its Impact on Farm Profit among Rural Farmers in Dryland od Sudan. Global Advanced Research Journal of Agricultural Science. 2(3): 88102

[2] Abdulrahaman, A.A. and Kolawole, O.M. (2008). Traditional Preparations and Uses of Maize in Nigeria. Traditional preparations and uses of maize in Nigeria. 201-208

[3] Abiyong, P.A. (2018). Economic Analysis of pig marketing in Kaduna State Nigeria, Unpublished PhD Thesis submitted to the Department of Agricultural Economics, Federal University of Agriculture, Makurdi, Nigeria.

[4] Ajala, M.K., Adeshinwa, A.O.K. and Mohammed, A.K. (2007). Characteristics of smallholder pig production in southern Kaduna Area of Kaduna State, Nigeria, American Eurasian. Journal of Agriculture and Environmental science. 2(2):182-188

[5] Bakari, H.R and Chamalwa, H.A.(2016). A Vector Autoregressive Cointegration and Vector Error Correction Model Approach for Financial Deepening indicators and Economic Growth in Nigeria. American Journal of Mathematical Analysis. 4(1): 1-6

[6] Chidozie, A. (2014). Adoption of cassava value added innovation and its implication on rural livelihood in Abia State.

[7] Dauda, M. and Ndanitsa, M. A. (2009). Economic Analysis of Timber Production Sawmill operation in some selected Local Government Area of Ogun State. Proceedings of the $23^{\text {rd }}$ National Conference of FAMAN, Sokoto. 198-208

[8] Damulak, F. (2012). Yam value chain, constraints and opportunities for small scale farmers in the middle belt Nigeria.

[9] Food Agriculture Organisation (2008)

[10] Food Agriculture Organisation Statistics (2012). http://faostat.fao.org. Accessed January 2012.

[11] Gani, B.S. and Adeoti, A.I. (2011). Analysis of market participation and poverty among farmers in Northern part of Taraba State. Journal of Economics. 2(1): 2236.

[12] Iken, J. E. and Amusa N.A. (2016). Review of Maize Research and Production in Nigeria. African Journal of Biotechnology. 3(6): 302-307

[13] Keyser, J.C. (2006). Definition of Methodology and Presentation of Templates for Value Chain Analysis Competitive Commercial Agriculture in Africa. Management Journal. 19(5). 413-437

[14] National Agricultural Extension and Research Liaison Services (NAERLS) (2017).

[15] Ogunniyi, L.T and Omoteso, O. A. (2011). Economic Analysis of Swine Production in Nigeria. A case study of Ibadan zone Oyo State. 35(2): 137-142

[16] Oladejo, J.A. and Adetunji, M.O. (2012). Department of Agricultural Economics, Ladoke Akintola university of technology, Ogbomosho, Oyo state, Nigeria. Agricultural Science Research Journals. 2(2): 77-83.

[17] Olayemi, J.K. (1982). Improved Marketing as a Strategy for Generating Increased Food Production, A Nigeria Experience. West African Journal of Agricultural Economics. 1(1): 21-26.

[18] Oruonye, E.D. and Ahmed, M.Y. (2017). Assessment of Environmental Effect of Abandoned Uranium Mine Site in Mika Village of Taraba State. International Journal of Geography and Geology. 6(4): 70-78

[19] Osundu, C.K., Ijioma, J.C., Anyiro, C.O. and Obike, K. (2014). Economic Analysis of Pig Production in Abia State, Nigeria. International Journal of Applied Research and Technology. 3(3):3-10

[20] Onuekwusi, G.C, Odoemelan L.E. and Kanu R.I. (2016). Capacity building on cocoyam value addition training for rural women in Abia State. 34-40

[21] Thomas, E. L., Johnston, K.L., Bell, J.D., Frost G.S. and Robertson M.D. (2010). Resistant Start Improves Insulin Sensitivity in Metabolic Syndrome. 27: 391 397

[22] Umeh, J.C., Penda, S.T. and Benjamin, C.A.(2011). Analysis of Economic Efficiency of Nigerian Small Scale Farmers: A parametric Frontier Approach. Journal of Economics. 2(2): 89-98 